Measure Guideline: Five Steps

To Implement the Public

Housing Authority Energy-

Efficient Unit Turnover Checklist

Christine Liaukus

Building America Research Alliance

July 2015
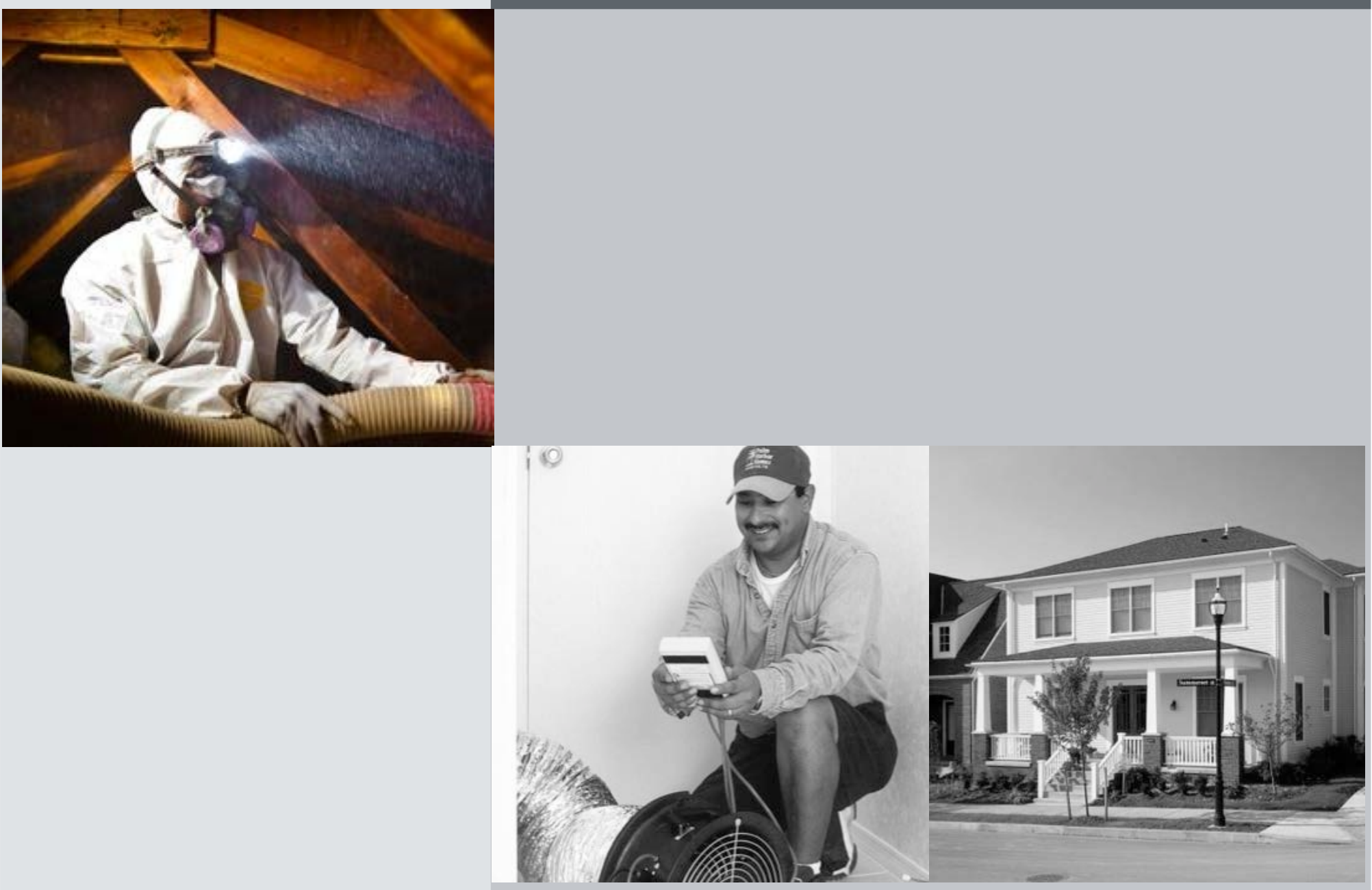


\section{NOTICE}

This report was prepared as an account of work sponsored by an agency of the United States government. Neither the United States government nor any agency thereof, nor any of their employees, subcontractors, or affiliated partners makes any warranty, express or implied, or assumes any legal liability or responsibility for the accuracy, completeness, or usefulness of any information, apparatus, product, or process disclosed, or represents that its use would not infringe privately owned rights. Reference herein to any specific commercial product, process, or service by trade name, trademark, manufacturer, or otherwise does not necessarily constitute or imply its endorsement, recommendation, or favoring by the United States government or any agency thereof. The views and opinions of authors expressed herein do not necessarily state or reflect those of the United States government or any agency thereof.

Available electronically at http://www.osti.gov/bridge

Available for a processing fee to U.S. Department of Energy and its contractors, in paper, from:

U.S. Department of Energy

Office of Scientific and Technical Information

P.O. Box 62

Oak Ridge, TN 37831-0062

phone: 865.576 .8401

fax: 865.576 .5728

email: mailto:reports@adonis.osti.gov

Available for sale to the public, in paper, from:

U.S. Department of Commerce

National Technical Information Service

5285 Port Royal Road

Springfield, VA 22161

phone: 800.553 .6847

fax: 703.605 .6900

email: orders@ntis.fedworld.gov

online ordering: http://www.ntis.gov/ordering.htm 


\title{
Measure Guideline: Five Steps to Implement the Public Housing Authority Energy-Efficient Unit Turnover Package
}

\author{
Prepared for: \\ The National Renewable Energy Laboratory \\ On behalf of the U.S. Department of Energy's Building America Program \\ Office of Energy Efficiency and Renewable Energy \\ 15013 Denver West Parkway \\ Golden, CO 80401 \\ NREL Contract No. DE-AC36-08GO28308 \\ Prepared by: \\ Christine Liaukus \\ Building America Research Alliance \\ 12932 SE Kent-Kangley Road, Suite 529 \\ Kent, WA 98030 \\ NREL Technical Monitor: Stacey Rothgeb \\ Prepared under Subcontract No. KNDJ-0-40336-05
}

July 2015 
The work presented in this report does not represent performance of any product relative to regulated minimum efficiency requirements.

The laboratory and/or field sites used for this work are not certified rating test facilities. The conditions and methods under which products were characterized for this work differ from standard rating conditions, as described.

Because the methods and conditions differ, the reported results are not comparable to rated product performance and should only be used to estimate performance under the measured conditions. 


\section{Contents}

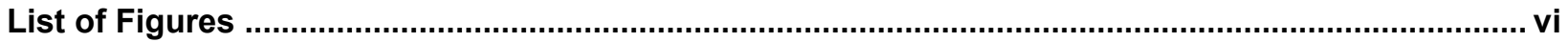

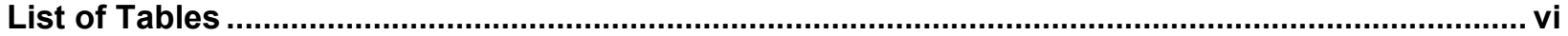

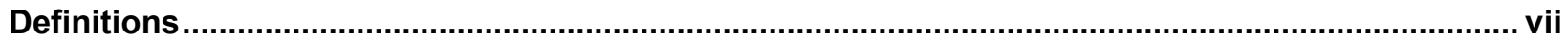

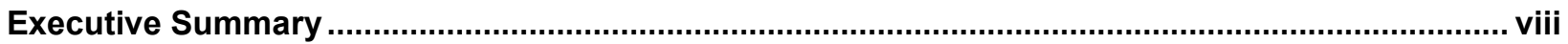

Implementing the Public Housing Authority Energy-Efficient Unit Turnover Package ...................... ix

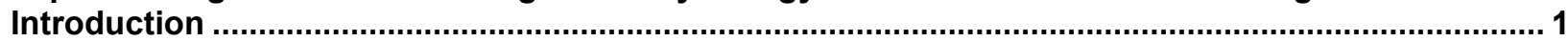

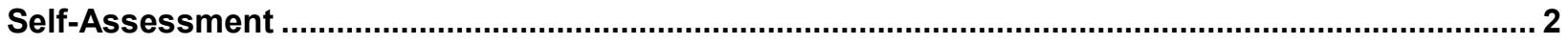

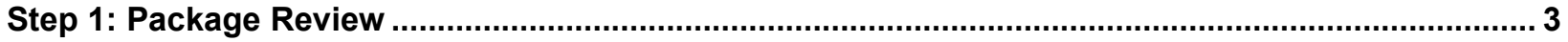

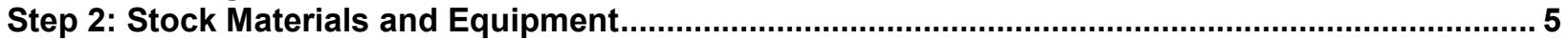

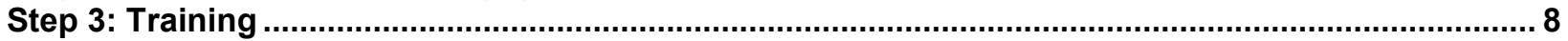

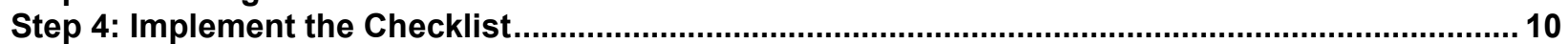

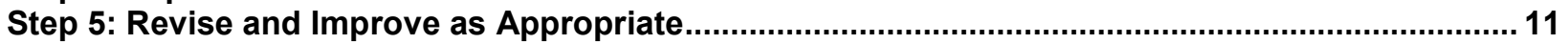

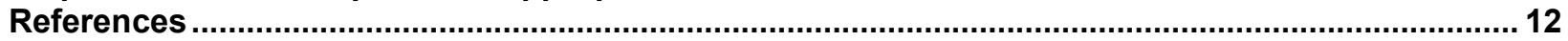

Appendix: Public Housing Authority Unit Turnover Protocol Checklist............................................ 13 


\section{List of Figures}

Figure 1. Testing of air leakage at window of public housing unit .................................................. 1

This figure was created by the Building America Research Alliance team.

\section{List of Tables}

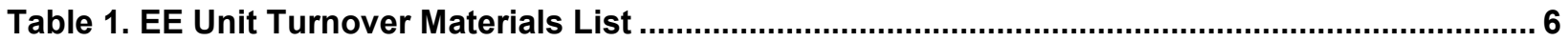

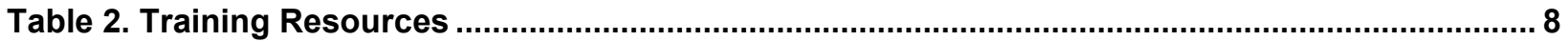

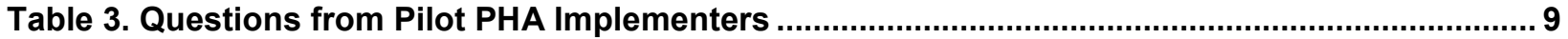

Table 4. Measure Issues Assessment/Potential Solution Matrix .................................................. 11

Unless otherwise noted, all tables were created by the Building America Research Alliance team. 


\section{Definitions}

EE Energy Efficient

HUD U.S. Department of Housing and Urban Development

HVAC Heating, Ventilating, and Air Conditioning

NREL National Renewable Energy Laboratory

PHA Public Housing Authority 


\section{Executive Summary}

This measure guideline can help public housing authorities (PHAs) use the Energy-Efficient (EE) Unit Turnover Package (ARIES 2014) to prepare for the installation of energy-efficiency measures during a typical PHA unit turnover. While a PHA is cleaning, painting, and readying a unit for a new resident, there is an opportunity to incorporate energy-efficiency measures to further improve the unit's performance. The measures on the list are simple enough to be implemented by in-house maintenance personnel, inexpensive enough to be folded into operating expenses without a capital budget, and fast enough to implement without substantially changing the number of days between occupancies (a critical factor for organizations whose demand for dwelling units far outweighs the supply). ${ }^{1}$ This guideline provides a five-step plan to implement the EE Unit Turnover Package in your PHA, from an initial self-assessment to package implementation.

This guideline is intended for PHAs, especially executive directors, physical plant and maintenance supervisors, and physical plant and maintenance team members.

The U.S. Department of Housing and Urban Development spends \$7 billion annually on utilities - almost twice as much energy is used per square foot in public housing than in market rate housing (HUD 2013). PHAs can help reduce the energy used in their communities incrementally through modest changes to unit turnover practices. This guide can help them do so.

Special thanks go to the Philadelphia Housing Authority, the Town of Islip (New York) Housing Authority, the Cleveland (Tennessee) Housing Authority, and the Ogle County (Illinois) Housing Authority for their participation and input.

\footnotetext{
${ }^{1}$ In 2011 there was a shortage of 4.6 million affordable housing units to extremely low income renters (Bravve et al. 2013).
} 


\section{Implementing the Public Housing Authority Energy-Efficient Unit Turnover Package}

The EE Unit Turnover Package best applies to housing authorities that can answer "yes" to the questions in the bulleted list below. If your PHA fits that profile, the package implementation may be a good fit for your organization.

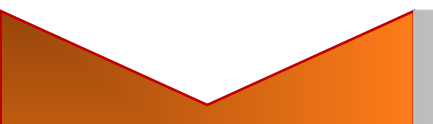

PACKAGE REVIEW

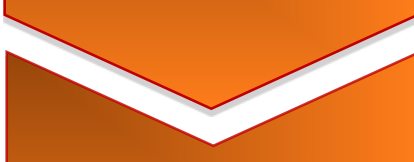

STOCK MATERIALS

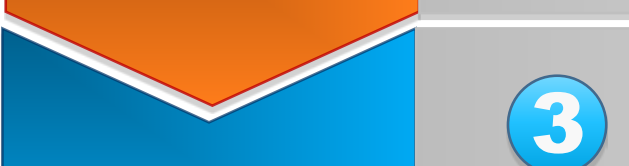

TRAIN

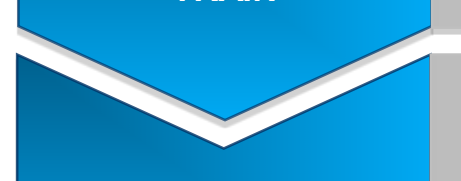

IMPLEMENT

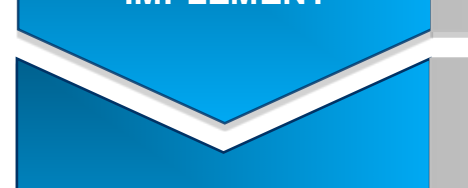

REVISE AS NEEDED

\section{Can your PHA answer "yes" to the following questions?}

- Can you invest $\$ 100$ in materials and 6 person hours per unit?

- Have at least $20 \%$ of your units not yet been weatherized?

- Is your annual unit turnover at least $20 \%$ ?

- Are your units primarily low-rise wood frame?

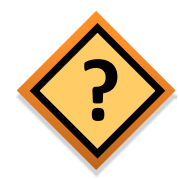

The package focuses on six major areas: interior air sealing, air conditioning, water, attic, lights, and ventilation. Review the measures in each area for applicability to your units.

The package is designed to use materials that are low cost and multipurpose. Refer to Figure 2 in the guideline for a materials list.

The National Renewable Energy Laboratory, Building America, and the Weatherization Assistance Program have resources that can help you prepare for package implementation (see Table 2).

Use the Checklist Protocol and Guidelines (see the Appendix) to implement the package in your next unit turnover.

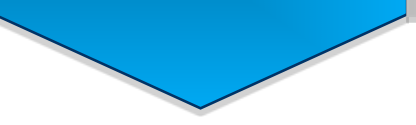

During implementation, use the protocol and guidance documents to note changes or adjustments that can improve your process and customize it to your team and building stock. 


\section{Introduction}

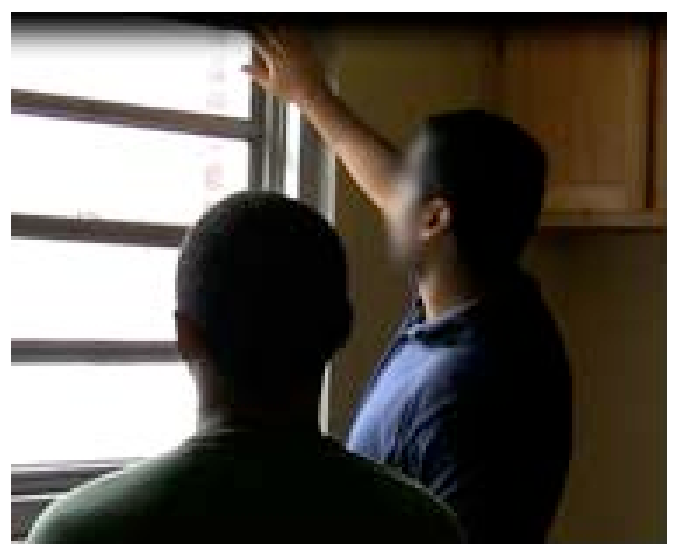

Figure 1. Testing of air leakage at window of public housing unit
The Energy-Efficient (EE) Unit Turnover Package is a set of prescriptive energy-efficiency measures that are designed to be incorporated into typical public housing unit turnover practices (see the Appendix). This package can fulfill an unmet need among public housing authorities (PHAs) and other providers of affordable housing for ways to reduce their utility costs. The package was developed by the Building America ARIES team and customized for implementation with three pilot PHAs in New York, Pennsylvania, and Tennessee; however, the measures can be applied to all U.S. climates. The package measures are simple enough to be implemented by in-house maintenance personnel, inexpensive enough to be folded into operating expenses without a capital budget, and fast enough to implement without substantially changing the number of days between occupancies (see Figure 1). This measure guideline provides a fivestep plan to implement the EE Unit Turnover Package in your PHA, from checklist review to revision and improvement. This guide was developed based on the pilot PHA implementations and on discussions with other PHAs that have adopted the package for future unit turnovers. 


\section{Self-Assessment}

The PHA EE Unit Turnover Package offers low-cost, practical, energy-efficiency measures that can be incorporated into typical unit turnover practices. The full EE unit checklist takes approximately 6 person hours ${ }^{2}$ to implement initially, and approximately $\$ 80-\$ 100$ worth of material. Implementation time should lessen as staff becomes more familiar with the measures. Modeling has shown the checklist to reduce energy use by $6 \%-12 \%{ }^{3}$ The package best applies to housing authorities that can answer "yes" to the following questions:

- Recognizing that PHAs are reimbursed by HUD for most energy expenses, is your PHA interested in reducing energy use at your sites?

- Is your PHA interested in low-cost energy-efficiency measures that can be implemented during unit turnover at a cost of approximately $\$ 80-\$ 100$ per unit in materials and an additional 6 person hours of labor?

- Have at least $20 \%$ of your units not benefited from the Weatherization Assistance Program in the last 10 years?

- Is your PHA's annual unit turnover at least $20 \%$ ?

- Is at least $20 \%$ of your building stock low rise (three or fewer stories) wood frame construction? ${ }^{4}$

If you answered "yes" to all these questions, the package should be a good fit for your organization. If you answered "yes" to the first two questions, the package may still be beneficial, but you'll want to review the checklist carefully to see how applicable the measures are to your units and how many units you can impact.

\footnotetext{
${ }^{2}$ This estimate is based on the implementation of the checklist in multiple dwelling units among three pilot PHAs (see Dentz et al. 2014).

${ }^{3}$ Energy modeling using BEopt 2.2 Energy Modeling software.

${ }^{4}$ The air-sealing measures in the checklist provide the most benefit for low-rise wood frame construction, but they can reduce infiltration in other construction types.
} 


\section{Step 1: Package Review}

The EE Unit Turnover Checklist is included in the Appendix. It focuses on six major areas:

- Interior air sealing

- Air conditioning

- Water

- Attic

- Lights

- Ventilation.

Review the checklist with your physical plant/maintenance supervisor(s) to:

- Assess whether any of the measures are already part of your unit turnover process. Your organization may already by implementing measures that are included in the checklist during unit turnover or unit maintenance. If so, the estimated time for implementation will decrease and fewer materials will be needed. The checklist is included in the Appendix as an editable document, so you can modify the measures as needed to dovetail with your current practices.

- Determine whether some of the measures are not applicable to your unit types. Some of the checklist items may not apply to any or all of your unit types. For example, attic insulation and attic access are addressed; this may not apply to your units. This again will reduce the cost of materials and time for implementation but will also reduce anticipated energy savings.

- Determine whether there may be practical or procedural adjustments needed to implement specific measures. Some measures may not be practical for your organization to implement, or other changes may need to be made to allow implementation. For instance, if your buildings are configured such that attics are not isolated from the dwelling units, work in the attic may be considered a capital project. As such, attic insulation may have to be installed as part of a separate effort. The recommended level of attic insulation to be installed will depend on your climate zone.

- Evaluate whether training is needed for the maintenance staff. Measures in each area should be within the capacity of a typical maintenance staff person but should be reviewed with the maintenance or physical plant staff supervisor to reveal whether additional training may be necessary. See Step 4 for training resources.

- Decide how best to implement the checklist. While the checklist is designed to be implemented fully at unit turnover, some PHAs have taken an incremental approach by implementing a few measures at a time during multiple turnovers. The advantage to this approach is that the change in practice is gradual; the disadvantage is that the full impact of potential energy savings is drawn out. Knowing when the unit will be accessible again is unpredictable. Another tack to consider is making checklist items part of your 
preventative maintenance work. This approach still allows your PHA to integrate measures into your current operational processes and typically ensures that a subset of measures will be implemented each year. In this way, an installation will be completed in a few years. The other benefit is that focusing on fewer measures may reduce your training needs and simplify quality control. A hybrid approach that includes installing certain measures during unit turnover and others during preventative maintenance visits may work best for your organization. This may reveal itself after some units are completed, at which time you can modify your approach based on your crews' experiences.

- Consider providing resident education. For lasting savings, consider informing residents about the energy-efficiency work that has been done in their units. This can help reduce measures being negated, such as the temperature on the water heater being turned down as part of the checklist work, and turned back up by the resident (a concern among PHAs that piloted the checklist). Enterprise Green Communities (2013) has extensive materials for resident engagement and education that can provide useful templates for creating community specific materials. 


\section{Step 2: Stock Materials and Equipment}

The EE Unit Turnover Checklist is designed to use materials that are low cost and multipurpose. Table 1 includes the checklist items and the materials needed for each measure. Materials amounts will depend on the size and number of the units involved. Some materials on the list are probably part of your inventory for normal unit maintenance; however, you may need to consider purchasing and storing some materials. Spray foam in particular has to be stored at the manufacturer-recommended temperature range and has a more limited shelf life when compared to other materials. The U.S. Department of Housing and Urban Development's guidelines for inventory and materials management and purchasing (HUD 2005) are also helpful for the EE Unit Turnover Checklist materials. 
Table 1. EE Unit Turnover Materials List

\begin{tabular}{|c|c|c|}
\hline & Item & Products \\
\hline $\begin{array}{c}\text { Interior Air/Duct } \\
\text { Sealing }\end{array}$ & $\begin{array}{l}\text { 1. Seal bottom of walls to floor with caulk or } \\
\text { foam } \\
\text { 2. Seal plumbing penetrations (all walls): } \\
\text { shower heads, under sinks, water heater } \\
\text { with caulk or foam } \\
\text { 3. Seal electrical penetrations (all walls, } \\
\text { ceilings): outlets, switches, behind } \\
\text { oven/fridge, telephone box, intercom, in } \\
\text { closet ceilings/floors with caulk or foam } \\
\text { 4. Regrout tile floors and walls } \\
\text { 5. Seal at base of bathtubs with caulk } \\
\text { 6. Seal ceiling penetrations at lighting fixtures } \\
\text { with foam } \\
\text { 7. Seal exhaust fan housing and duct boots to } \\
\text { ceiling (remove grills and seal with foil } \\
\text { heating, ventilating, and air-conditioning } \\
\text { [HVAC] tape) } \\
\text { 8. Replace entry door weather stripping if } \\
\text { necessary; use V-seal if possible } \\
\text { 9. Caulk around entry door frame } \\
\text { 10. Foam inside door latches } \\
\text { 11. Caulk around windows frame }\end{array}$ & $\begin{array}{l}\text { 1.89-in. } \times 50 \text {-yd } 322 \text { multipurpose HVAC foil tape } \\
\text { V-flex weather strip }(7 / 8 \text { in. } \times 17 \mathrm{ft}) \\
\text { Caulk or window and door sealant } \\
\text { Multipurpose latex insulating foam sealant } \\
\text { Caulk or window and door sealant }\end{array}$ \\
\hline Air Conditioning & $\begin{array}{l}\text { 1. Clean air-conditioning filter if necessary } \\
\text { 2. Seal around air-conditioning unit } \\
\text { 3. Clean/replace air handler filter if present }\end{array}$ & $\begin{array}{c}\text { N/A } \\
\text { Caulk or multipurpose latex insulating foam } \\
\text { sealant } \\
\text { Vacuum or compressed air; replacement filter }\end{array}$ \\
\hline Water & $\begin{array}{l}\text { 1. Check and adjust hot water temperature } \\
\text { 2. Insulate hot water tank }\end{array}$ & $\begin{array}{l}\text { Thermometer, screwdriver to adjust tank } \\
\text { temperature } \\
\text { Water tank insulation jacket and compatible } \\
\text { fastening tape }\end{array}$ \\
\hline
\end{tabular}




\begin{tabular}{|c|c|c|}
\hline & Item & Products \\
\hline & $\begin{array}{l}\text { 3. Insulate exposed domestic hot water pipes } \\
\text { 4. Correct faucet/shower drips } \\
\text { 5. Check shower flow and install low-flow } \\
\text { showerhead if necessary }\end{array}$ & $\begin{array}{c}\text { Polyethylene tube pipe insulation } \\
\text { Replacement O rings/rubber washers } \\
\text { Low-flow ( }<2 \text { GPM)shower head, thread } \\
\text { sealant/compound }\end{array}$ \\
\hline Attic & $\begin{array}{l}\text { 1. Check and fix attic insulation } \\
\text { 2. Seal wall top plates in attic, if accessible } \\
\text { 3. Add attic hatch insulation, gluing } 2 \text {-in. rigid } \\
\text { foam to backside of hatch } \\
\text { 4. Add attic hatch gasket or strip of rigid } \\
\text { foam }(1 \mathrm{in} . \times 1 / 4 \text { in.) }\end{array}$ & $\begin{array}{l}\text { Blown-in or batt insulation } \\
\text { Multipurpose latex insulating foam sealant } \\
\text { 2-in. rigid foam insulation, construction adhesive } \\
\text { Gasket or weather stripping, } \\
1 / 2 \text { in. } \times 50 \mathrm{ft}, 3 / 16 \text { in. }\end{array}$ \\
\hline
\end{tabular}




\section{Step 3: Training}

The National Renewable Energy Laboratory (NREL), Building America, and the Weatherization Assistance Program have resources that can help prepare for EE Unit Turnover Checklist implementation. NREL's Standard Work Specifications for Multi-Family Home Energy Upgrades provides detailed specifications and objectives for all the measures in the EE Unit Turnover Checklist (NREL 2013a). Among the many resources on the Waptac.org website is the Standardized Curricula (WAP 2014). Within the curricula are the slide presentations for Weatherization Installer/Technician Fundamentals 2.0 and Weatherization Installer/Technician Intermediate, both of which address building science concepts and energy-efficiency measure installation methods. Building America's Solutions Center and publications library also have applicable resources. Table 2 pairs the specific resources to the major areas of the EE Unit Checklist.

Table 2. Training Resources

\begin{tabular}{|c|c|}
\hline EE Checklist Item & Training Resources \\
\hline Interior Air Sealing & $\begin{array}{l}\text { Standard Work Specifications for Multi-Family Home Energy Upgrades } \\
\text { (NREL 2013a) } \\
\text { Section 3: Air Sealing, applicable sections to your project } \\
\text { Appendix B: General Information on Spray Polyurethane Foam } \\
\text { Weatherization Installer/Technician Fundamentals } 2.0 \text { (WAP 2014) } \\
\text { The House as a System } \\
\text { Building Science Basics } \\
\text { Identifying and Air Sealing the Building Envelope }\end{array}$ \\
\hline Air Conditioning & $\begin{array}{l}\text { "A Homeowner's Guide to Window Air Conditioner Installation for Efficiency } \\
\text { and Comfort" (NREL 2013) }\end{array}$ \\
\hline Water & $\begin{array}{l}\text { Weatherization Installer/Technician Fundamentals } 2.0 \text { (WAP 2014) } \\
\text { Plumbing Overview }\end{array}$ \\
\hline Attic & $\begin{array}{l}\text { Standard Work Specifications for Multi-Family Home Energy Upgrades } \\
\text { (NREL 2013a) } \\
\text { Section 4: Insulation, applicable sections to your project } \\
\text { Weatherization Installer/Technician Fundamentals } 2.0 \text { (WAP 2014) } \\
\text { Identifying and Air Sealing the Building Envelope } \\
\text { Loose Fill Insulation } \\
\text { Measure Guideline: Guide to Attic Air Sealing (Lstiburek 2014) }\end{array}$ \\
\hline Lights & $\begin{array}{l}\text { Standard Work Specifications for Multi-Family Home Energy Upgrades } \\
\text { (NREL 2013a) } \\
\text { Section 7: Plug Load } \\
\text { Subtopic: Lighting } \\
\text { 7.8003.11 Lamp Replacement } \\
\text { 7.8003.14 Fixture Replacement }\end{array}$ \\
\hline Ventilation & $\begin{array}{l}\text { Standard Work Specifications for Multi-Family Home Energy Upgrades } \\
\text { (NREL 2013a) } \\
\text { Section 6: Ventilation, applicable sections to your project } \\
\text { Homeowner's Guide to Ventilation (NYSERDA 2007) }\end{array}$ \\
\hline
\end{tabular}


Table 3 provides actual questions and answers from pilot PHA EE Unit Checklist installations.

Table 3. Questions from Pilot PHA Implementers

\begin{tabular}{c|c}
\hline $\begin{array}{c}\text { Selected Maintenance Crew } \\
\text { Questions (Paraphrased) }\end{array}$ & Building America Answers \\
\hline $\begin{array}{c}\text { Will air sealing at the light } \\
\text { fixture cause it to overheat? }\end{array}$ & $\begin{array}{c}\text { Air sealing from inside the dwelling unit between the light } \\
\text { fixture and the gypsum will not cause the fixture to overheat } \\
\text { and will reduce air leakage between the attic and living space. } \\
\text { Air sealing between dwelling units ensures that all unit exterior } \\
\text { walls are sealed. It also helps reduce noise, odors, and pests } \\
\text { from neighboring units. }\end{array}$ \\
$\begin{array}{c}\text { between dwelling units? } \\
\text { Don't weep holes in brick } \\
\text { walls provide ventilation? }\end{array}$ & $\begin{array}{c}\text { Weep holes drain moisture within the brick wall assembly but } \\
\text { do not provide ventilation air to the dwelling unit. }\end{array}$ \\
$\begin{array}{c}\text { If we insulate, aren't we } \\
\text { reducing air leakage? }\end{array}$ & $\begin{array}{c}\text { Fibrous insulation material will not stop airflow. To reduce air } \\
\text { leakage, air sealing has to be done with caulk, foam, or a rigid } \\
\text { material that stops air flow. (See the training resources on air } \\
\text { sealing.) }\end{array}$ \\
$\begin{array}{c}\text { Can't we use duct tape for } \\
\text { duct sealing? }\end{array}$ & $\begin{array}{c}\text { Duct tape will not last for the life of the system. Foil tape and } \\
\text { mastic (painted on or applied with gloves) are recommended as } \\
\text { more durable materials for duct sealing. }\end{array}$ \\
$\begin{array}{c}\text { What about residents who } \\
\text { turn the water heater back } \\
\text { up after we turn it down? }\end{array}$ & $\begin{array}{c}\text { Discuss this with your supervisor so that resident educational } \\
\text { material can be circulated about the measures you are } \\
\text { implementing. }\end{array}$ \\
\hline
\end{tabular}




\section{Step 4: Implement the Checklist}

Use the Checklist Protocol and Guidelines (see the Appendix) to implement the checklist in your next unit turnover. You may fully adopt the list or incrementally add measures over several turnovers. We recommend that you implement the checklist as fully as possible to reap the greatest savings as soon as possible because you cannot predict when you will next have full access to the unit.

The first implementation also offers an opportunity to train additional staff on the measures being implemented. In-field training can help galvanize preparatory training that was done with Web or print resources. It also reveals field conditions that are specific to your own building stock.

Quality control is critical to the successful implementation of the checklist. In addition to the training resources available from the Weatherization Program and Building America, NREL has developed the Standard Work Specifications for Home Energy Professionals (NREL 2013b). These "Guidelines for Home Energy Professionals," available for single-family homes, and multifamily buildings, can help PHAs establish quality standards, worker certifications, and standard work specifications. 


\section{Step 5: Revise and Improve as Appropriate}

As the checklist is being implemented, use the protocol and guidance documents to note changes or adjustments that can improve your process and customize it to your team and building stock. If your PHA is relatively small, this may be as simple as marking up the checklist and making changes for the next unit. In larger PHAs with more than one crew, you'll want to obtain feedback from crew managers and members. Table 4 may help facilitate a structured assessment of potential measure and or process changes.

Table 4. Measure Issues Assessment/Potential Solution Matrix

\begin{tabular}{|c|c|c|}
\hline Measure & Issue & Potential Solution \\
\hline $\begin{array}{l}\text { Seal Bottoms of Walls } \\
\text { to Floor With Foam }\end{array}$ & $\begin{array}{l}\text { Foam can't be stored on } \\
\text { maintenance truck because it } \\
\text { will freeze in winter. }\end{array}$ & $\begin{array}{c}\text { Provide an indoor lock box at each } \\
\text { community so the foam can be kept } \\
\text { at the right temperature and secure } \\
\text { from theft or vandalism. }\end{array}$ \\
\hline All Measures & $\begin{array}{l}\text { How do we check for } \\
\text { compliance once the } \\
\text { maintenance staff has been } \\
\text { trained on the checklist? }\end{array}$ & $\begin{array}{l}\text { Implement a spot-checking policy } \\
\text { by sampling } 10 \% \text { of units and } \\
\text { informing the maintenance } \\
\text { supervisor. }\end{array}$ \\
\hline
\end{tabular}

As changes are made to the checklist measures, implementation strategies, or other aspect of the EE Unit Checklist, the supporting documents can be modified and updated to reflect those changes and carry them forward at your PHA. 


\section{References}

ARIES. Public Housing Authority Unit Turnover Protocol Checklist. New York: ARIES, 2014.

Bravve, E., Bolton, M., Crawley, S. Out Of Reach. Washington, DC: National Low Income Housing Coalition, 2013. Accessed June 3, 2015:

http://nlihc.org/sites/default/files/oor/2013 OOR.pdf.

Dentz, J., Conlin, F., Podorson, D., and Alaigh, K. Public Housing: A Tailored Approach to Energy Retrofits, 2014. Golden, CO: National Renewable Energy Laboratory. Accessed June 3, 2015:

http://apps1.eere.energy.gov/buildings/publications/pdfs/building_america/public housing_retrof its.pdf.

Lstiburek, J. Measure Guideline: Guide to Attic Air Sealing, 2014. Golden, CO: National Renewable Energy Laboratory. Accessed June 1, 2015:

http://apps1.eere.energy.gov/buildings/publications/pdfs/building america/measure guideline at tic_airsealing.pdf.

Enterprise Green Communities. Resident Engagement Strategies, 2013.Accessed December 4, 2014: https://s3.amazonaws.com/KSPProd/ERC Upload/0086978.pdf.

HUD. Housing Manager's Procedures Manual Public Housing Agency, 2005. Washington, DC: U.S. Department of Housing and Urban Development. Accessed June 3, 2015: https://portal.hud.gov/hudportal/documents/huddoc?id=DOC 9211.pdf.

HUD. 2013. "HUD Green Academy Training.” Washington DC: U.S. Department of Housing and Urban Development.

NREL. Standard Work Specifications for Multi-Family Home Energy Upgrades, 2013a.Golden, CO: National Renewable Energy Laboratory. Accessed June 1, 2015:

https://sws.nrel.gov/sites/default/files/sws_multifamily.pdf.

---. “Standard Work Specifications Tool.” 2013b. Accessed November 12, 2014 :

https://sws.nrel.gov/.

---. "A Homeowner's Guide to Window Air Conditioner Installation for Efficiency and Comfort." 2013c.Golden, CO: National Renewable Energy Laboratory. Accessed June 1, 2015: http://www.nrel.gov/docs/fy13osti/58187.pdf.

NYSERDA. Homeowner's Guide to Ventilation, 2012. Albany: NYSERDA.

WAP. 2014. "Weatherization Assistance Program Standardized Curricula, accessed December 4, 2014: http://waptac.org/Training-Tools/WAP-Standardized-Curricula.aspx. 


\section{Appendix: Public Housing Authority Unit Turnover Protocol Checklist}

Address and apartment number:

\begin{tabular}{|c|c|c|c|}
\hline & ITEM & COMPLETE & N/A \\
\hline \multirow{11}{*}{ 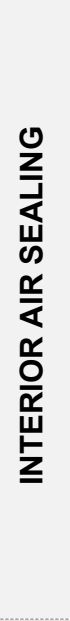 } & 1. Seal bottom of walls to floor if carpet removed and/or where accessible & & \\
\hline & $\begin{array}{l}\text { 2. Seal plumbing penetrations (all walls): shower heads, under sinks, water } \\
\text { heater }\end{array}$ & & \\
\hline & $\begin{array}{l}\text { 3. Seal electrical penetrations (all walls, ceilings): outlets, switches, behind } \\
\text { oven/fridge, telephone box, intercom, in closet ceilings/floors }\end{array}$ & & \\
\hline & 4. Re-grout tile floors and walls & & \\
\hline & 5. Seal at base of bathtubs, toilets & & \\
\hline & 6. Seal ceiling penetrations at lighting fixtures & & \\
\hline & 7. Seal exhaust fan housing and ducts boots to ceiling & & \\
\hline & 8. Replace entry door weather stripping if necessary & & \\
\hline & 9. Caulk around entry door frame and windows & & \\
\hline & 10. Foam inside door latches (all doors) & & \\
\hline & 11. Seal at stair treads and risers & & \\
\hline \multirow{3}{*}{ 晏 } & 12. Clean AC filter if necessary & & \\
\hline & 13. Seal around $A C$ unit & & \\
\hline & 14. Clean/replace air handler filter if present & & \\
\hline \multirow{5}{*}{$\frac{\substack{u \\
\frac{\alpha}{3}}}{3}$} & 15. Check and adjust hot water temperature & & \\
\hline & 16. Insulate hot water tank & & \\
\hline & 17. Insulate exposed DHW pipes & & \\
\hline & 18. Correct faucet/shower drips & & \\
\hline & $\begin{array}{l}\text { 19. Check shower flow and install low-flow showerhead ( } 2 \mathrm{gpm} \text { or less) if } \\
\text { necessary }\end{array}$ & & \\
\hline \multirow{4}{*}{$\underset{\mathbb{E}}{\stackrel{U}{E}}$} & 20. Check and fix attic insulation & & \\
\hline & 21. Seal wall top plates in attic if accessible & & \\
\hline & 22. Add attic hatch insulation & & \\
\hline & 23. Add attic hatch gasket & & \\
\hline \multirow{2}{*}{$\begin{array}{l}\stackrel{\infty}{!} \\
\text { 売 } \\
\underline{J}\end{array}$} & 24. Check and replace light bulbs & & \\
\hline & 25. Install LED surface mount light fixtures & & \\
\hline \multirow{3}{*}{ 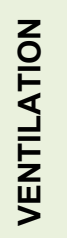 } & 26. Check bath and kitchen exhaust fan flow & & \\
\hline & 27. Clean bath and kitchen exhaust fans & & \\
\hline & 28. Check bath and kitchen exhaust fan condition & & \\
\hline
\end{tabular}

Address:

Signature: 


\section{Public Housing Authority: Checklist Protocol and Guidelines}

The following guidelines are intended for use when apartments are prepared for new residents. All activities are intended to be low-cost, achievable by in-house staff with readily available tools and materials, and fit within the time available during unit turnover. The guidelines are organized by topic and include information on location, how to accomplish the task, materials required and photos illustrating typical conditions. Measures within each topic are not prioritized.(ARIES, 2014)

A note about air sealing: If the dwelling unit has natural or induced draft combustion appliances, precautions need to be taken to ensure that air sealing the dwelling does not create an unsafe situation such as backdrafting. It is best to seek the advice of an energy professional that can perform a combustion safety test before proceeding with air sealing.

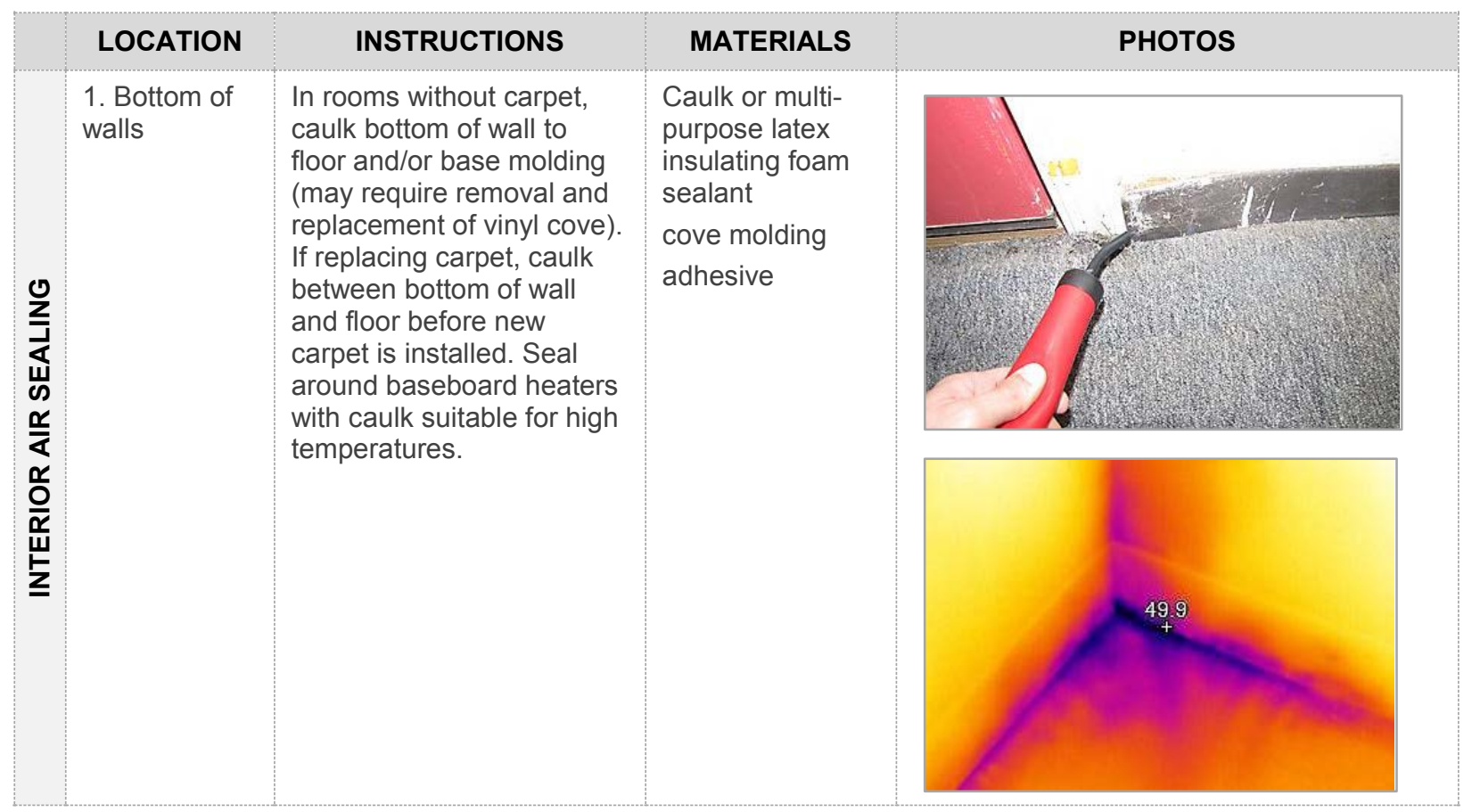




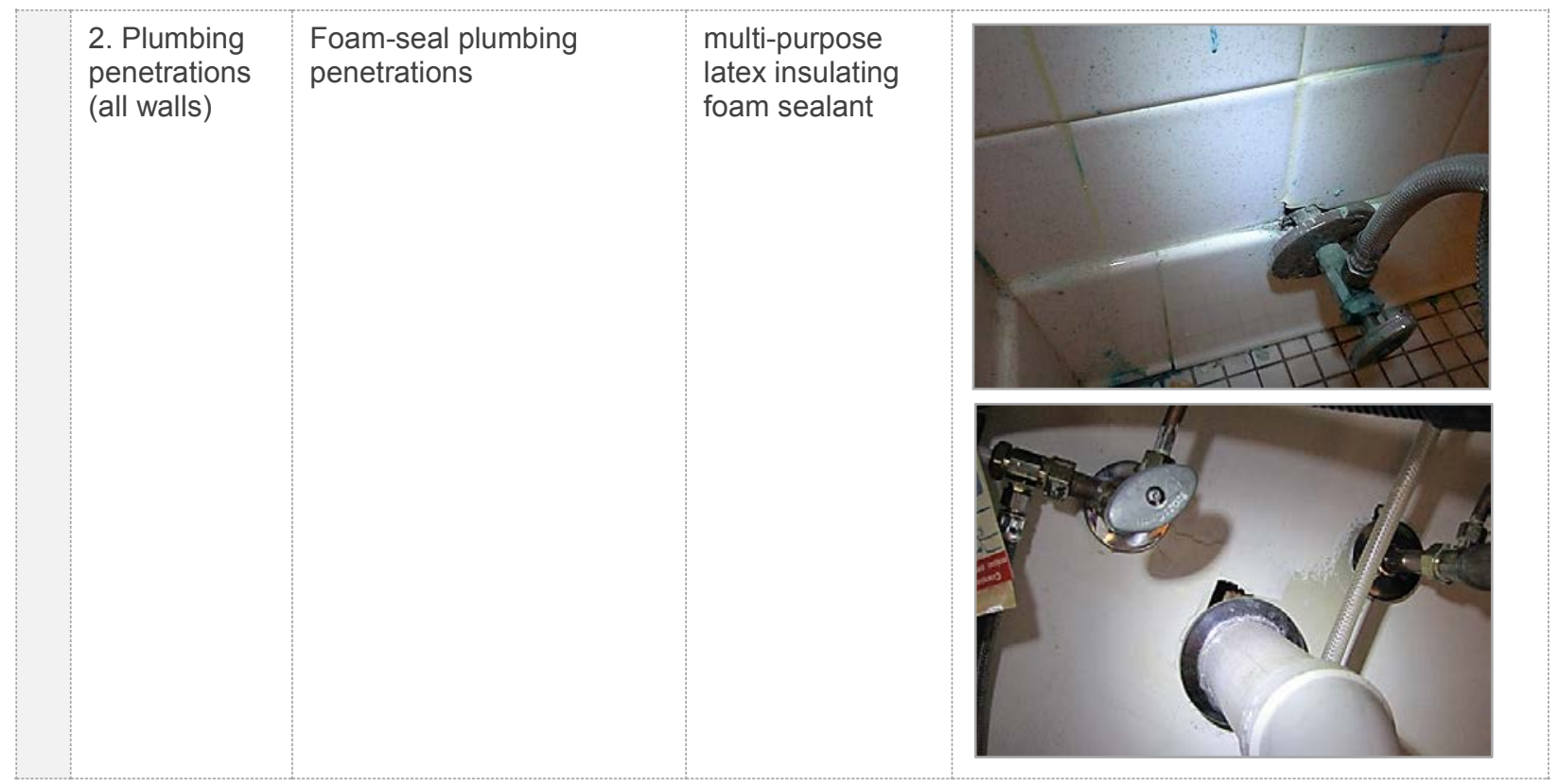




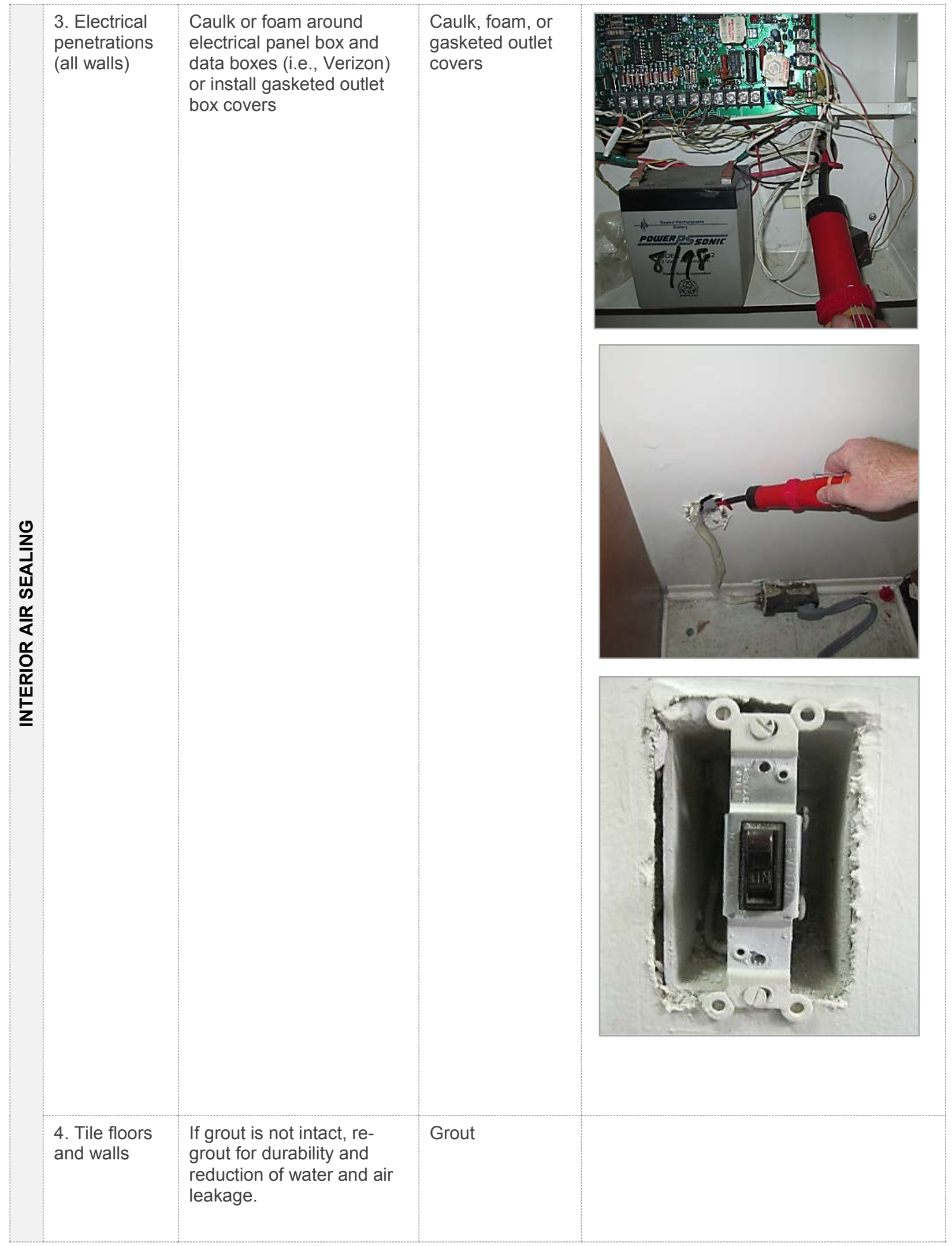




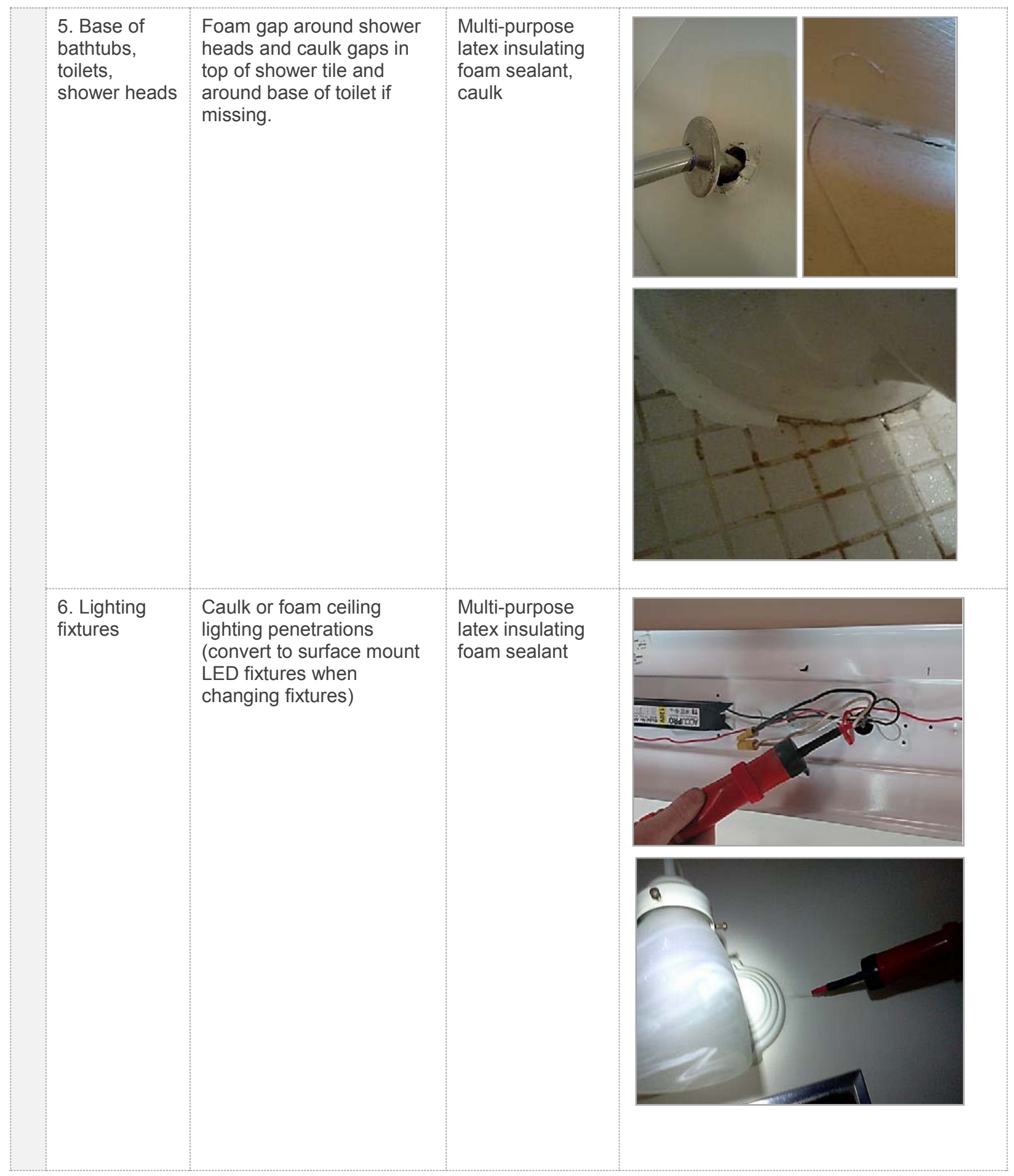




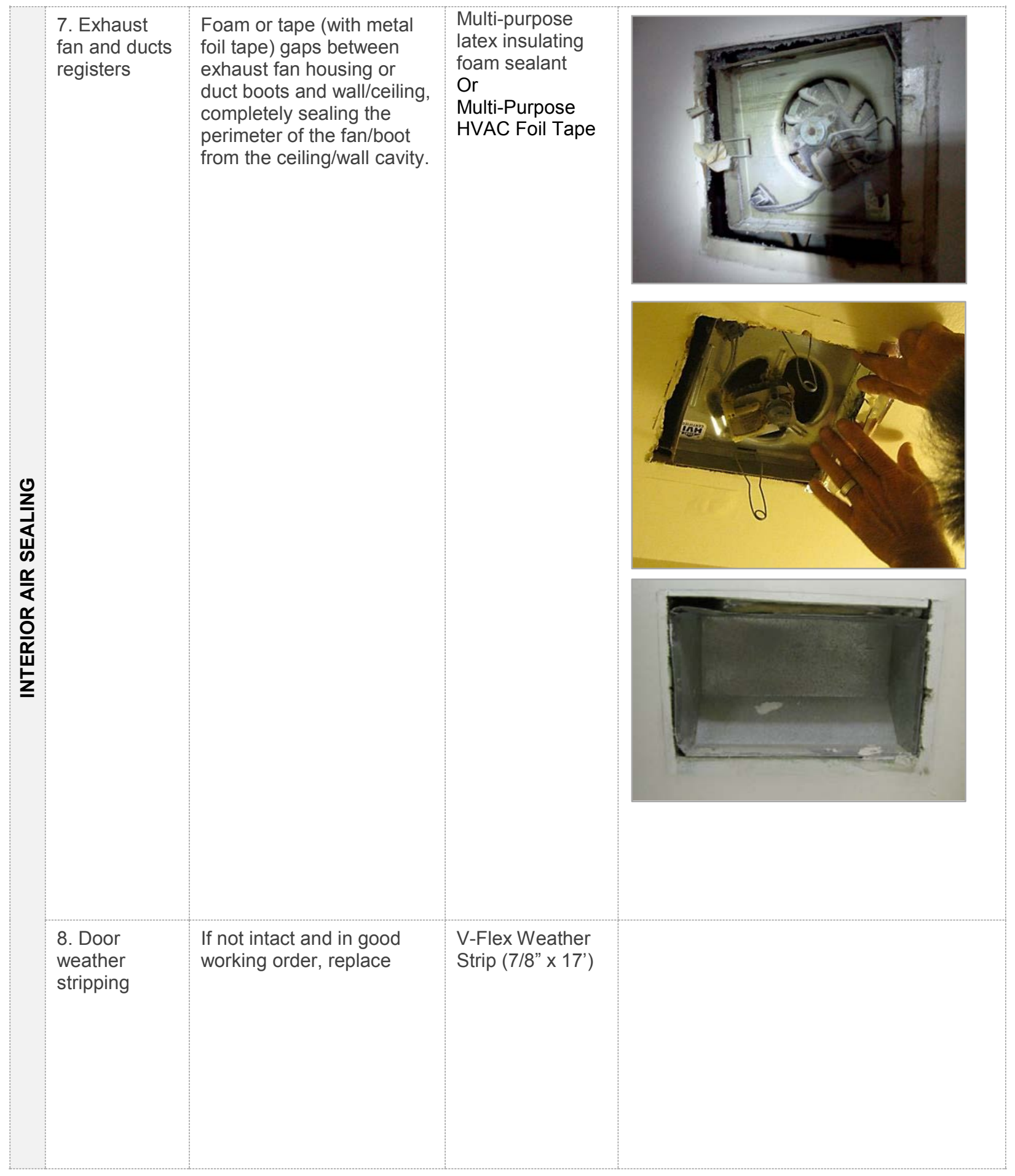




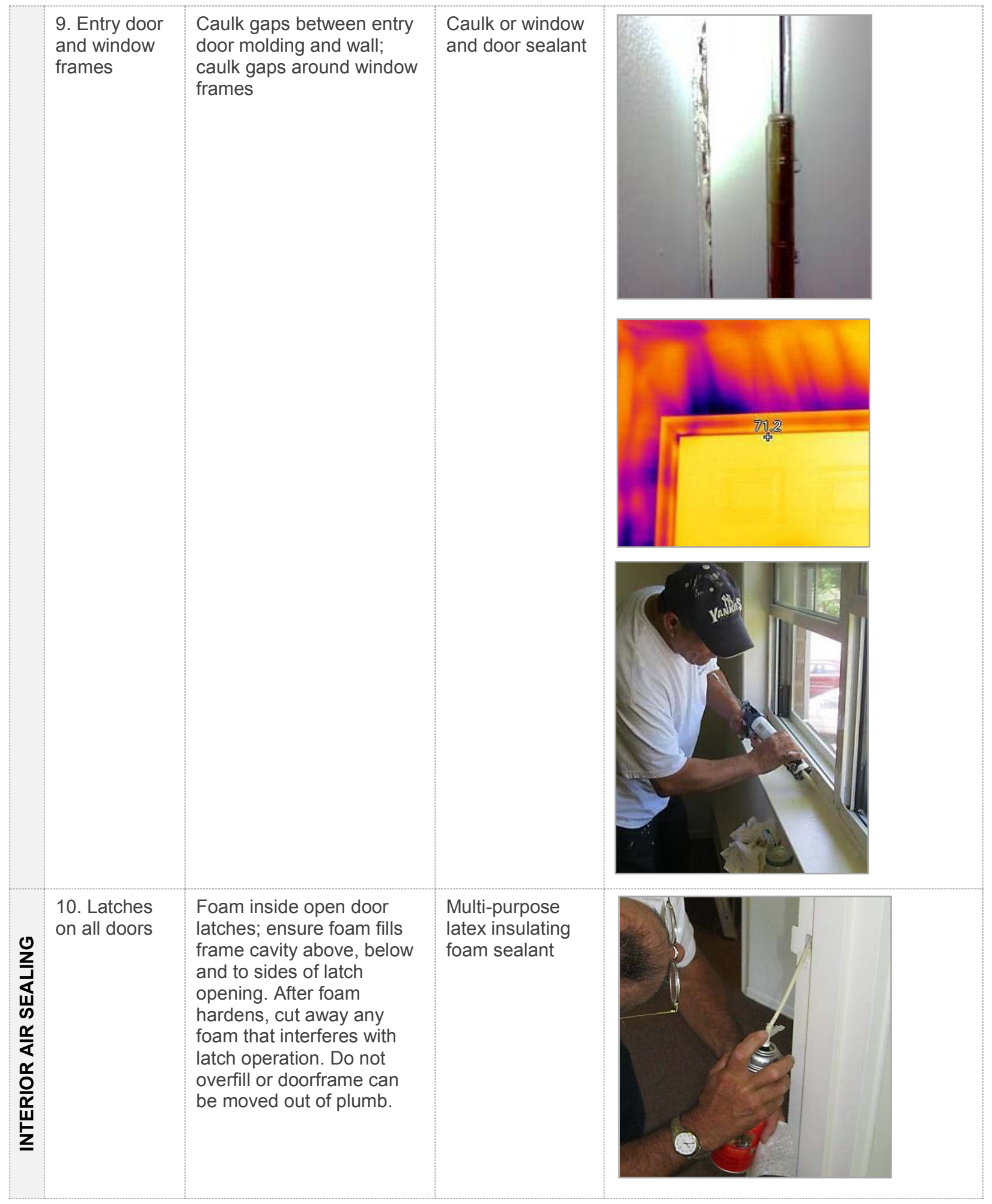




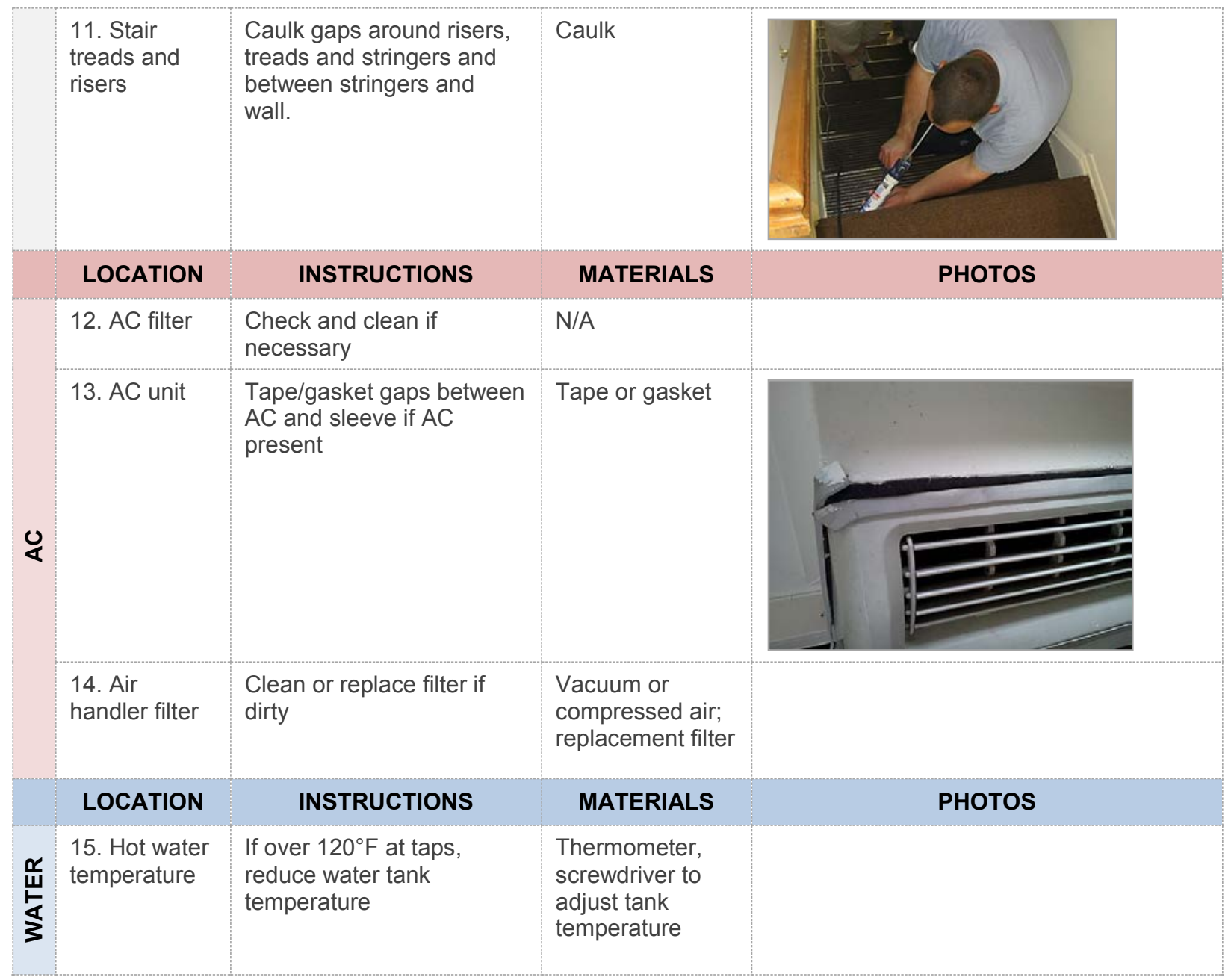




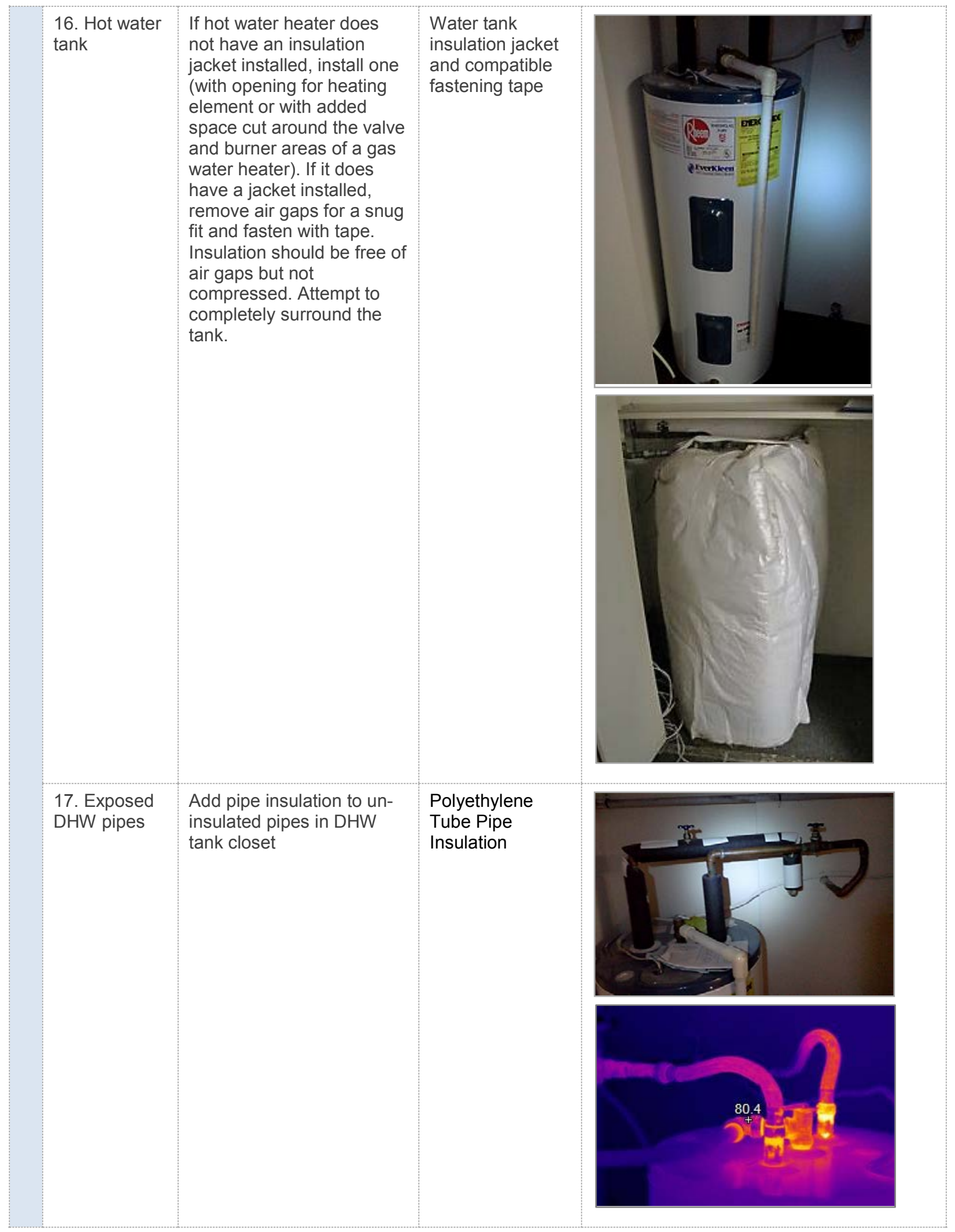




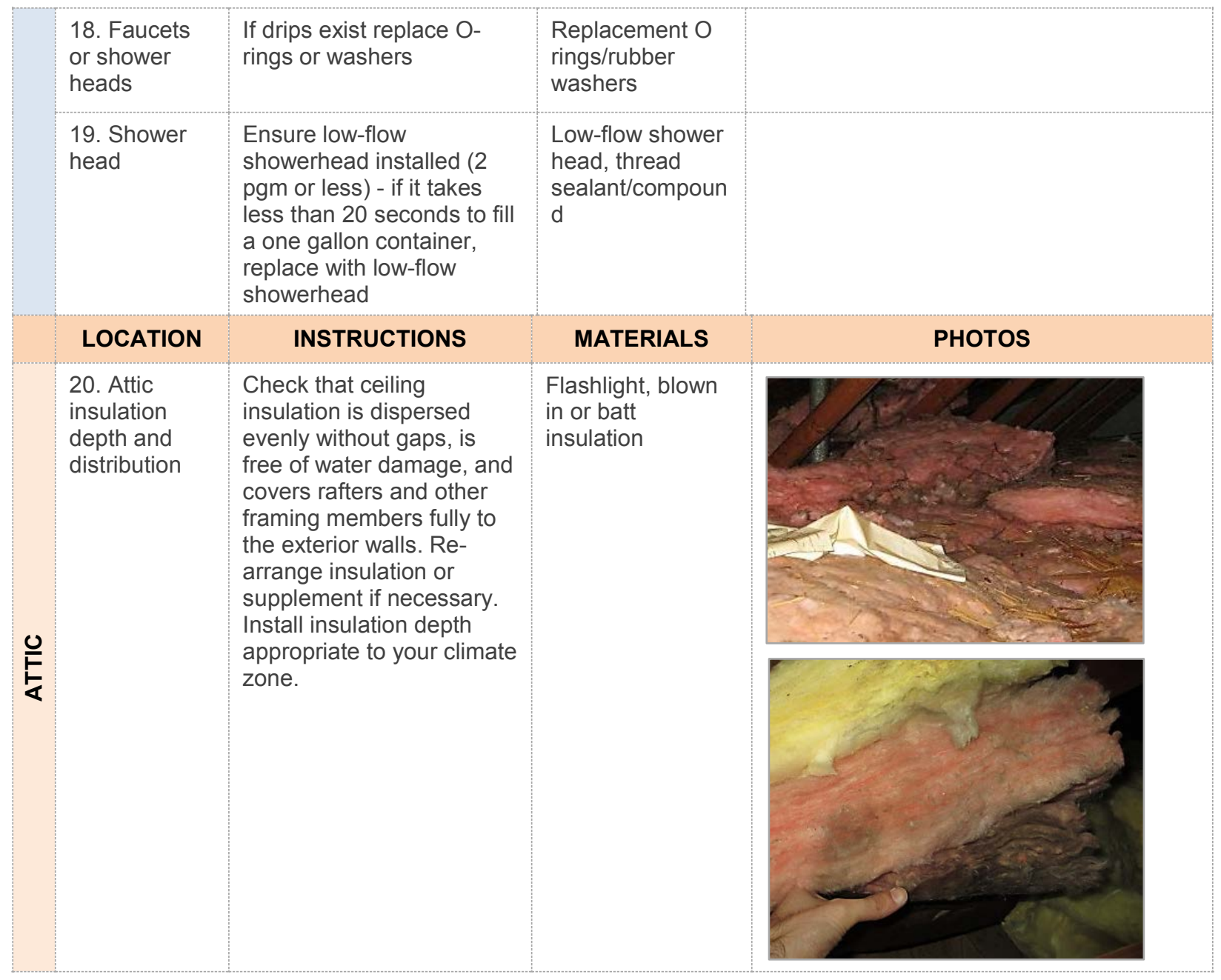


